\title{
DESIGNING FOR DIGITAL TRANSFORMATION: LESSONS FOR INFORMATION SYSTEMS RESEARCH FROM THE STUDY OF ICT AND SOCIETAL CHALLENGES
}

\author{
Ann Majchrzak \\ Marshall School of Business, University of Southern California, \\ Los Angeles, CA 90089 U.S.A. \{majchrza@usc.edu\} \\ M. Lynne Markus \\ Bentley University, 175 Forest Street, \\ Waltham, MA 02452 U.S.A. \{mlmarkus@bentley.edu\} \\ Jonathan Wareham \\ ESADE - Ramon Llull University, Av. de Pedralbes, 60-62, \\ 08034 Barcelona, SPAIN \{jonathan.wareham@esade.edu\}
}

\section{Introduction}

The 14 papers in this special issue discuss the roles of information and communication technologies (ICTs) in a wide range of major societal challenges, including employment, climate, health, and human migration. An overview of the special issue process can be found in the Appendix. A tabular summary of the 14 accepted papers is shown in Table 1.

The importance of the societal challenges addressed in these 14 papers makes this special issue significant and interesting in its own right. However, some readers may believe the special issue has little to offer to them, particularly if they study enterprise technologies in Western corporations. Nothing could be further from the truth.

In this introductory commentary, we discuss four major implications of these papers for any IS research that aims to contribute to the improvement of societal or business conditions. The implications are

- That IS researchers interested in societal or business change should expand their definitions of theory to include theories of the problem and theories of the solution; however, any single paper should only have to work with one of these two alternative theory types.
- That IS researchers interested in societal or business change should explicitly define the ICT artifact in both broad and specific ways, include affordances and constraints provided by the ICT artifact, and explicitly examine the unintended consequences of the ICT artifact.

- That IS researchers interested in societal or business change should consider emergent digital designing as a replacement for organizations.

- That IS researchers interested in societal and business change should couple research findings with public policy and regulation recommendations where relevant.

\section{Embracing an Expanded Definition of Theory}

Editing this special issue has reinforced our beliefs and those of others (e.g., Avgerous 2013; Gregor 2006; Grover et al 2008; Markus 2014; Rivard 2014; Weber 2012) that our field has problems with "theory" and needs to adopt a broader definition of what theory means. During the review process, reviewers frequently took exception to what we thought to be promising papers. In many cases, reviewers' objections 
Table 1. Summaries of Papers in Special Issue: ICT and Societal Challenges

\begin{tabular}{|c|c|c|c|c|c|c|}
\hline Authors & $\begin{array}{c}\text { Societal } \\
\text { Challenge } \\
\text { and Context }\end{array}$ & $\begin{array}{l}\text { Artifact/Socio- } \\
\text { technical } \\
\text { System }\end{array}$ & \begin{tabular}{|c|} 
Theoretical Lens(es), \\
Causal Mechanisms \\
and/or Hypothesized \\
Affordances/ \\
Constraints
\end{tabular} & Methods & $\begin{array}{l}\text { Theorized and/or } \\
\text { Observed } \\
\text { Consequences }\end{array}$ & Policy Implications \\
\hline \multicolumn{7}{|c|}{ Research Articles } \\
\hline $\begin{array}{l}\text { Deng, Joshi, } \\
\text { and Galliers }\end{array}$ & $\begin{array}{l}\text { Effects of micro- } \\
\text { work on crowd- } \\
\text { workers in the } \\
\text { context of } \\
\text { Amazon's } \\
\text { Mechanical Turk } \\
\text { platform }\end{array}$ & $\begin{array}{l}\text { Platform features } \\
\text { and policies } \\
\text { (governance, } \\
\text { compensation, } \\
\text { etc.), combined } \\
\text { with task } \\
\text { requesters' } \\
\text { platform use } \\
\text { practices } \\
\end{array}$ & $\begin{array}{l}\text { Value sensitive } \\
\text { design theory; values } \\
\text { classification; } \\
\text { empowerment and } \\
\text { marginalization }\end{array}$ & $\begin{array}{l}\text { Compensated } \\
\text { surveys (both } \\
\text { closed and open } \\
\text { questions) with } \\
\text { crowdworkers; } \\
\text { iterative qualitative } \\
\text { coding of workers' } \\
\text { value statements }\end{array}$ & $\begin{array}{l}\text { Crowdworkers experi- } \\
\text { enced dual effects: } \\
\text { simultaneous } \\
\text { empowerment and } \\
\text { marginalization; negative } \\
\text { consequences were } \\
\text { traced to AMT's platform } \\
\text { features and policies and } \\
\text { requesters' practices }\end{array}$ & $\begin{array}{l}\text { Crowdwork platform } \\
\text { operators should be } \\
\text { more transparent and } \\
\text { should build in platform } \\
\text { features and policies } \\
\text { that help prevent/ } \\
\text { redress requester } \\
\text { scams and other } \\
\text { abusive practices }\end{array}$ \\
\hline $\begin{array}{l}\text { Miranda, Young, } \\
\text { and Yetgin }\end{array}$ & $\begin{array}{l}\text { Openness and } \\
\text { fairness of public } \\
\text { discourse in the } \\
\text { U.S. concerning } \\
\text { the proposed } \\
\text { Stop Online } \\
\text { Piracy Act } \\
\text { (SOPA) }\end{array}$ & $\begin{array}{l}\text { Traditional and } \\
\text { online (social) } \\
\text { media: TV, } \\
\text { newspapers, } \\
\text { Twitter, YouTube } \\
\text { as employed by } \\
\text { media organiza- } \\
\text { tions, affected } \\
\text { organizations, } \\
\text { and individual } \\
\text { commentators } \\
\end{array}$ & $\begin{array}{l}\text { Mass media theory; } \\
\text { affordances and } \\
\text { constraints theory; } \\
\text { social movement } \\
\text { theory (e.g., discourse } \\
\text { framing); } \\
\text { emancipating } \\
\text { (democratizing) } \\
\text { versus hegemonizing } \\
\text { (dominating) public } \\
\text { discourse }\end{array}$ & $\begin{array}{l}\text { Qualitative coding } \\
\text { and quantitative } \\
\text { analysis of commu- } \\
\text { nication and social } \\
\text { media; cross- } \\
\text { media compari- } \\
\text { sons; hypothesis } \\
\text { testing }\end{array}$ & $\begin{array}{l}\text { Dual effects were } \\
\text { observed; relative to } \\
\text { traditional media, social } \\
\text { media are emancipatory in } \\
\text { some ways; hegemonic in } \\
\text { others; lean social media } \\
\text { attenuate some effects } \\
\text { and reinforce others; } \\
\text { some inevitable evils } \\
\text { accompany the societal } \\
\text { benefits of social media }\end{array}$ & $\begin{array}{l}\text { Activists should foster } \\
\text { inclusiveness in digital } \\
\text { communities; activists } \\
\text { and platform owners } \\
\text { should display public } \\
\text { discourse by stance; } \\
\text { platform owners } \\
\text { should implement } \\
\text { algorithms that down- } \\
\text { weight heckling posts }\end{array}$ \\
\hline $\begin{array}{l}\text { Selander and } \\
\text { Jarvenpaa }\end{array}$ & $\begin{array}{l}\text { Human rights, } \\
\text { political injustice, } \\
\text { and false } \\
\text { imprisonment, as } \\
\text { addressed by the } \\
\text { Swedish affiliate } \\
\text { of the social } \\
\text { movement } \\
\text { organization } \\
\text { Amnesty } \\
\text { International } \\
\end{array}$ & $\begin{array}{l}\text { Attempts to } \\
\text { leverage social } \\
\text { media to engage } \\
\text { latent supporters }\end{array}$ & \begin{tabular}{|l|} 
Resource mobilization \\
theory of collective \\
action; values \\
influencing the design \\
of digital action \\
repertoires in two \\
dimensions of \\
collective action \\
space (interaction and \\
engagement)
\end{tabular} & \begin{tabular}{|l|} 
In-depth qualitative \\
case study (inter- \\
views and observa- \\
tions) focusing on \\
three strategic \\
initiatives by the \\
social movement \\
organization; \\
coding and \\
categorization
\end{tabular} & $\begin{array}{l}\text { Values build supporters' } \\
\text { relationships with the } \\
\text { social movement organi- } \\
\text { zation and with each } \\
\text { other; however, strong ties } \\
\text { among supporters are } \\
\text { problematic when ties to } \\
\text { the organization are weak: } \\
\text { supporters challenged the } \\
\text { organization's policies }\end{array}$ & $\begin{array}{l}\text { Social movement } \\
\text { organizations should } \\
\text { engage key users in } \\
\text { exploring the uses of } \\
\text { social media; to miti- } \\
\text { gate risk, social move- } \\
\text { ment organizations } \\
\text { should allow sup- } \\
\text { porters more } \\
\text { autonomy and a role in } \\
\text { governance }\end{array}$ \\
\hline $\begin{array}{l}\text { Venkatesh, Rai, } \\
\text { Sykes, and } \\
\text { Aljafari }\end{array}$ & $\begin{array}{l}\text { Infant mortality in } \\
\text { rural India as } \\
\text { addressed by a } \\
\text { government- } \\
\text { sponsored } \\
\text { initiative }\end{array}$ & \begin{tabular}{|l} 
Health informa- \\
tion kiosks staffed \\
by trained inter- \\
mediaries, \\
accompanied by \\
training of adult \\
women in remote \\
Indian villages
\end{tabular} & $\begin{array}{l}\text { Social network theory; } \\
\text { social epidemiology; } \\
\text { social influence; } \\
\text { strong and weak ties; } \\
\text { advice and hindrance } \\
\text { ties }\end{array}$ & $\begin{array}{l}\text { Longitudinal (7- } \\
\text { year) study of } \\
\text { infant mortality in } \\
10 \text { rural villages, } \\
\text { before and after } \\
\text { kiosk introduction, } \\
\text { compared with } 10 \\
\text { control villages; } \\
\text { surveys admin- } \\
\text { istered via inter- } \\
\text { views; quantitative } \\
\text { hypothesis testing }\end{array}$ & $\begin{array}{l}\text { Use of eHealth kiosk } \\
\text { promotes seeking } \\
\text { professional medical care } \\
\text { and reduces infant } \\
\text { mortality; hindrance ties } \\
\text { are powerful; advice ties } \\
\text { can help counter } \\
\text { traditional practices }\end{array}$ & $\begin{array}{l}\text { Policy makers should } \\
\text { deploy staffed health } \\
\text { information kiosks, } \\
\text { combined with training } \\
\text { and other long-term } \\
\text { social interventions, to } \\
\text { mitigate shortages of } \\
\text { healthcare facilities in } \\
\text { rural areas }\end{array}$ \\
\hline \multicolumn{7}{|l|}{ Research Notes } \\
\hline $\begin{array}{l}\text { Chan, Ghose, } \\
\text { and Seamans }\end{array}$ & $\begin{array}{l}\text { Racial hate crime } \\
\text { in the United } \\
\text { States, online and } \\
\text { offline } \\
(2001-2008)\end{array}$ & Internet websites & \begin{tabular}{|l|} 
Conventional belief \\
that increased avail- \\
ability of hate-related \\
online content \\
promotes offline hate \\
crimes
\end{tabular} & $\begin{array}{l}\text { Secondary econo- } \\
\text { metric analysis of } \\
\text { data from various } \\
\text { official sources } \\
\text { including FBI, } \\
\text { FCC, Census } \\
\text { Bureau }\end{array}$ & $\begin{array}{l}\text { A robust positive } \\
\text { relationship exists } \\
\text { between broadband } \\
\text { provision and hate crimes } \\
\text { (but not with the formation } \\
\text { of new hate groups) in } \\
\text { areas with high levels of } \\
\text { racism }\end{array}$ & $\begin{array}{l}\text { Technology-based } \\
\text { monitoring and filtering } \\
\text { solutions and counter- } \\
\text { speech tactics are of } \\
\text { limited utility; data- } \\
\text { driven approaches for } \\
\text { identifying lone-wolf } \\
\text { perpetrators are more } \\
\text { promising }\end{array}$ \\
\hline
\end{tabular}


Table 1. Summaries of Papers in Special Issue: ICT and Societal Challenges (Continued)

\begin{tabular}{|c|c|c|c|c|c|c|}
\hline Authors & $\begin{array}{c}\text { Societal } \\
\text { Challenge } \\
\text { and Context }\end{array}$ & $\begin{array}{l}\text { Artifact/Socio- } \\
\text { technical } \\
\text { System }\end{array}$ & \begin{tabular}{|c|} 
Theoretical Lens(es), \\
Causal Mechanisms \\
and/or Hypothesized \\
Affordances/ \\
Constraints
\end{tabular} & Methods & $\begin{array}{l}\text { Theorized and/or } \\
\text { Observed } \\
\text { Consequences }\end{array}$ & Policy Implications \\
\hline $\begin{array}{l}\text { Díaz Andrade } \\
\text { and Doolin }\end{array}$ & $\begin{array}{l}\text { Social inclusion of } \\
\text { multi-ethnic } \\
\text { international } \\
\text { refugees } \\
\text { repatriated to } \\
\text { New Zealand }\end{array}$ & $\begin{array}{l}\text { Desktop com- } \\
\text { puter and Internet } \\
\text { access coupled } \\
\text { with training for } \\
\text { families with } \\
\text { school-aged } \\
\text { children as part of } \\
\text { a comprehensive } \\
\text { package of } \\
\text { government- } \\
\text { provided social } \\
\text { services }\end{array}$ & $\begin{array}{l}\text { ICT for social inclu- } \\
\text { sion and development } \\
\text { (ICTD); } \\
\text { developmental capa- } \\
\text { bilities (individual } \\
\text { freedom to make use } \\
\text { of resources); } \\
\text { information-seeking, } \\
\text { communication, } \\
\text { identity expression, } \\
\text { social connection, } \\
\text { participation }\end{array}$ & \begin{tabular}{|l|} 
Interviews in \\
homes or \\
community \\
locations; \\
qualitative thematic \\
analysis
\end{tabular} & $\begin{array}{l}\text { E-mail communication } \\
\text { helps refugees } \\
\text { compensate for lack of } \\
\text { English language } \\
\text { proficiency; online literacy } \\
\text { fosters offline literacy; } \\
\text { maintaining online ties } \\
\text { with home country } \\
\text { increases social inclusion } \\
\text { in new country }\end{array}$ & $\begin{array}{l}\text { ICT access and } \\
\text { literacy training can } \\
\text { foster the social } \\
\text { inclusion of refugees; } \\
\text { developmental use of } \\
\text { ICT often requires the } \\
\text { assistance of } \\
\text { intermediaries, } \\
\text { including family } \\
\text { members }\end{array}$ \\
\hline $\begin{array}{l}\text { Ganju, Pavlou, } \\
\text { and Banker }\end{array}$ & \begin{tabular}{|l} 
National well- \\
being (citizens' \\
achievement of \\
their full \\
potential)_in \\
contrast to \\
national \\
economic \\
productivity
\end{tabular} & $\begin{array}{l}\text { Use of ICT for } \\
\text { education, health } \\
\text { information, } \\
\text { communication, } \\
\text { etc. }\end{array}$ & $\begin{array}{l}\text { Argument that ICT } \\
\text { may promote well- } \\
\text { being, not only } \\
\text { productivity }\end{array}$ & $\begin{array}{l}\text { Secondary econo- } \\
\text { metric analysis of } \\
\text { data from the } \\
\text { Gallup World Poll } \\
\text { in } 160 \text { countries } \\
(2006-2014) \text { and } \\
\text { from the World } \\
\text { Bank database }\end{array}$ & $\begin{array}{l}\text { ICT use is associated with } \\
\text { measures of national well- } \\
\text { being; in less developed } \\
\text { countries, use of mobile } \\
\text { phones is associated with } \\
\text { well-being; in more } \\
\text { developed countries, well- } \\
\text { being is associated with } \\
\text { use of the internet and } \\
\text { fixed-line as well as } \\
\text { mobile telephones }\end{array}$ & $\begin{array}{l}\text { Less developed } \\
\text { countries should invest } \\
\text { in mobile data } \\
\text { technology }\end{array}$ \\
\hline $\begin{array}{l}\text { Jha, } \\
\text { Pinsonneault, } \\
\text { and Dubé }\end{array}$ & $\begin{array}{l}\text { Poverty among } \\
\text { smallholder } \\
\text { farmers in India } \\
\text { as targeted by the } \\
\text { social entrepre- } \\
\text { neurial organiza- } \\
\text { tion eKutir }\end{array}$ & $\begin{array}{l}\text { ICT-enabled } \\
\text { social networking } \\
\text { and information- } \\
\text { based services } \\
\text { for soil testing } \\
\text { and seed selec- } \\
\text { tion, delivered } \\
\text { through a network } \\
\text { of individual } \\
\text { entrepreneurs } \\
\text { who work for } \\
\text { compensation }\end{array}$ & $\begin{array}{l}\text { Ecosystems; commu- } \\
\text { nities of practice; } \\
\text { access to information- } \\
\text { based services that } \\
\text { meet critical needs }\end{array}$ & $\begin{array}{l}\text { Case study, inter- } \\
\text { views with multiple } \\
\text { stakeholder groups }\end{array}$ & $\begin{array}{l}\text { The platform-enabled } \\
\text { ecosystem continues to } \\
\text { evolve; use of services } \\
\text { appears sustainable; } \\
\text { farmers and entrepre- } \\
\text { neurs receive benefits } \\
\text { from use }\end{array}$ & $\begin{array}{l}\text { Partner organizations, } \\
\text { intermediaries (indi- } \\
\text { vidual entrepreneurs), } \\
\text { and an appropriate } \\
\text { business model (com- } \\
\text { pensation scheme) are } \\
\text { essential to success; } \\
\text { scale up gradually } \\
\text { from an initial critical } \\
\text { application }\end{array}$ \\
\hline $\begin{array}{l}\text { Ketter, Peters, } \\
\text { Collins, and } \\
\text { Gupta }\end{array}$ & $\begin{array}{l}\text { Electricity market } \\
\text { dynamics; use of } \\
\text { a simulation } \\
\text { platform by } \\
\text { autonomous } \\
\text { interdisciplinary } \\
\text { teams of experts } \\
\text { in industry and } \\
\text { academia }\end{array}$ & $\begin{array}{l}\text { An series of open } \\
\text { competitions, } \\
\text { hosted by a } \\
\text { research team, } \\
\text { supported by a } \\
\text { simulation plat- } \\
\text { form for building } \\
\text { and testing con- } \\
\text { tributed electricity } \\
\text { market algorithms }\end{array}$ & \begin{tabular}{|l|} 
Open software \\
development; com- \\
petitive gaming; social \\
learning
\end{tabular} & $\begin{array}{l}\text { Design science; } \\
\text { action research; } \\
\text { evaluation } \\
\text { research }\end{array}$ & $\begin{array}{l}\text { Significant evidence of } \\
\text { community learning was } \\
\text { found; emergence of } \\
\text { undesirable and } \\
\text { unexpected simulation } \\
\text { outcomes }\end{array}$ & $\begin{array}{l}\text { Desirable energy } \\
\text { management out- } \\
\text { comes cannot all be } \\
\text { achieved simul- } \\
\text { taneously; energy } \\
\text { management goals } \\
\text { must be prioritized } \\
\text { politically }\end{array}$ \\
\hline $\begin{array}{l}\text { Leonardi, } \\
\text { Bailey, Diniz, } \\
\text { Sholler, and } \\
\text { Nardi }\end{array}$ & $\begin{array}{l}\text { Financial exclu- } \\
\text { sion; secure } \\
\text { delivery of } \\
\text { government } \\
\text { benefit payments } \\
\text { to "unbanked" } \\
\text { people in remote } \\
\text { areas of Brazil }\end{array}$ & $\begin{array}{l}\text { Complex system } \\
\text { of "correspondent } \\
\text { banking" in which } \\
\text { banks partnered } \\
\text { with retail stores } \\
\text { and post offices } \\
\text { to offer banking } \\
\text { services via POS } \\
\text { terminals or } \\
\text { computers (with } \\
\text { barcode readers, } \\
\text { card readers, and } \\
\text { PIN pads) }\end{array}$ & $\begin{array}{l}\text { Implementation } \\
\text { theory; adaptive } \\
\text { structuration theory; } \\
\text { appropriation of ICT }\end{array}$ & $\begin{array}{l}\text { Interviews in two } \\
\text { settings (retail } \\
\text { stores and post } \\
\text { offices); archival } \\
\text { data analysis; } \\
\text { qualitative within- } \\
\text { and across-setting } \\
\text { analyses }\end{array}$ & $\begin{array}{l}\text { The implementation of } \\
\text { complex systems (those } \\
\text { with ill-defined user groups } \\
\text { and process changes in } \\
\text { addition to ICT) involves } \\
\text { "multiplex appropriations" } \\
\text { (of policies, procedures, } \\
\text { role definitions, etc.); a } \\
\text { wide gap exist between } \\
\text { intended and actual uses } \\
\text { of the technology: "corre- } \\
\text { spondents" entered codes } \\
\text { for clients, counseled } \\
\text { them, and mediated for } \\
\text { them with institutions }\end{array}$ & $\begin{array}{l}\text { Dynamic and multiplex } \\
\text { appropriations by } \\
\text { various intermediaries } \\
\text { are critical to the } \\
\text { implementation and } \\
\text { functioning of complex } \\
\text { systems; partners } \\
\text { should be encouraged } \\
\text { to develop their own } \\
\text { social incentives for } \\
\text { evolving their } \\
\text { intermediary roles }\end{array}$ \\
\hline
\end{tabular}


Table 1. Summaries of Papers in Special Issue: ICT and Societal Challenges (Continued)

\begin{tabular}{|c|c|c|c|c|c|c|}
\hline Authors & $\begin{array}{c}\text { Societal } \\
\text { Challenge } \\
\text { and Context }\end{array}$ & $\begin{array}{l}\text { Artifact/Socio- } \\
\text { technical } \\
\text { System }\end{array}$ & $\begin{array}{l}\text { Theoretical Lens(es), } \\
\text { Causal Mechanisms } \\
\text { and/or Hypothesized } \\
\text { Affordances/ } \\
\text { Constraints }\end{array}$ & Methods & $\begin{array}{l}\text { Theorized and/or } \\
\text { Observed } \\
\text { Consequences }\end{array}$ & Policy Implications \\
\hline $\begin{array}{l}\text { Leong, Pan, } \\
\text { Newell, and Cui }\end{array}$ & $\begin{array}{l}\text { Rural develop- } \\
\text { ment in two } \\
\text { villages in China } \\
\text { that participated } \\
\text { in the Alibaba- } \\
\text { sponsored } \\
\text { Taobao Villages } \\
\text { program (Taobao } \\
\text { is an online } \\
\text { marketplace) }\end{array}$ & $\begin{array}{l}\text { A program of } \\
\text { rural develop- } \\
\text { ment to stimulate } \\
\text { online business } \\
\text { startups in } \\
\text { remote areas } \\
\text { through training } \\
\text { and provision of } \\
\text { online and } \\
\text { support services }\end{array}$ & $\begin{array}{l}\text { Ecosystems; } \\
\text { community-driven } \\
\text { development; self- } \\
\text { organization; experi- } \\
\text { mentation and } \\
\text { learning; ICT support } \\
\text { for market-making } \\
\text { (e.g., aggregation of } \\
\text { supply and demand, } \\
\text { search) }\end{array}$ & $\begin{array}{l}\text { Comparative case } \\
\text { study; interviews } \\
\text { and focus groups; } \\
\text { archival research }\end{array}$ & $\begin{array}{l}\text { Economic vibrancy } \\
\text { provided opportunities for } \\
\text { villagers; leadership } \\
\text { (intermediary roles) } \\
\text { emerged; some negative } \\
\text { outcomes emerged such } \\
\text { as out-migration and } \\
\text { environmental } \\
\text { degradation }\end{array}$ & $\begin{array}{l}\text { Local community } \\
\text { development through } \\
\text { online business } \\
\text { incubation is a viable } \\
\text { alternative to govern- } \\
\text { ment financial aid; } \\
\text { intermediaries play a } \\
\text { critical role in the suc- } \\
\text { cess of such programs }\end{array}$ \\
\hline McGrath & $\begin{array}{l}\text { Identity } \\
\text { verification for } \\
\text { delivery of } \\
\text { government ser- } \\
\text { vices in Nigeria } \\
\text { and other } \\
\text { countries }\end{array}$ & $\begin{array}{l}\text { Biometric smart } \\
\text { cards, introduced } \\
\text { via information } \\
\text { campaigns and } \\
\text { enrollment pro- } \\
\text { cesses, the use } \\
\text { of which was } \\
\text { mandated for } \\
\text { delivery of } \\
\text { various govern- } \\
\text { ment services } \\
\text { (e.g., voting, } \\
\text { residency per- } \\
\text { mits, payments) }\end{array}$ & $\begin{array}{l}\text { Identity services } \\
\text { evoke public distrust } \\
\text { regarding civil } \\
\text { liberties; suspicion } \\
\text { (distrust only) pro- } \\
\text { motes failure; } \\
\text { ambivalence } \\
\text { (coexistent trust and } \\
\text { distrust) enables } \\
\text { success }\end{array}$ & $\begin{array}{l}\text { Comparative case } \\
\text { analysis-primary } \\
\text { Nigerian case } \\
\text { compared to two } \\
\text { other published } \\
\text { cases }\end{array}$ & $\begin{array}{l}\text { Some governments are } \\
\text { more successful than } \\
\text { others in generating trust } \\
\text { and achieving citizen } \\
\text { adoption of identity } \\
\text { services }\end{array}$ & $\begin{array}{l}\text { Successful introduction } \\
\text { of identity verification } \\
\text { (via generating a } \\
\text { measure of trust in } \\
\text { addition to distrust) } \\
\text { requires a circum- } \\
\text { scribed development } \\
\text { goal, that is widely } \\
\text { publicized, broadly } \\
\text { shared, and achiev- } \\
\text { able in the short term }\end{array}$ \\
\hline $\begin{array}{l}\text { Oreglia and } \\
\text { Srinivasan }\end{array}$ & $\begin{array}{l}\text { Empowerment of } \\
\text { women in rural } \\
\text { and low-income } \\
\text { communities in } \\
\text { China and India }\end{array}$ & $\begin{array}{l}\text { Mobile telephony } \\
\text { and use of } \\
\text { intermediated } \\
\text { personal } \\
\text { computers } \\
\text { (kiosks) in } \\
\text { telecenters }\end{array}$ & $\begin{array}{l}\text { Information and } \\
\text { communication } \\
\text { technologies and } \\
\text { development (ICTD); } \\
\text { intermediation in } \\
\text { technology use; } \\
\text { empowerment theory }\end{array}$ & $\begin{array}{l}\text { Ethnographic field- } \\
\text { work in multiple } \\
\text { locations in China } \\
\text { and India; compar- } \\
\text { ative case analysis; } \\
\text { open-ended and } \\
\text { semi-structured } \\
\text { interviews, obser- } \\
\text { vation, and parti- } \\
\text { cipant observation } \\
\text { in research partici- } \\
\text { pants' homes, } \\
\text { workplaces, and } \\
\text { villages between } \\
2004 \text { and } 2011 \\
\end{array}$ & \begin{tabular}{|l|} 
Women may become \\
empowered (able to \\
renegotiate gendered \\
power structures and \\
remake their identities) by \\
intermediating ICT use for \\
others (rather than \\
through their own personal \\
use of ICT)
\end{tabular} & $\begin{array}{l}\text { Development } \\
\text { specialists should be } \\
\text { aware of entrenched } \\
\text { structural conditions } \\
\text { that limit the ability to } \\
\text { ICT to engender } \\
\text { change; specialists } \\
\text { should focus on the } \\
\text { role of women as } \\
\text { intermediaries in ICT } \\
\text { use and on the social } \\
\text { support they need to } \\
\text { enact that role }\end{array}$ \\
\hline $\begin{array}{l}\text { Srivastava, Teo, } \\
\text { and Devaraj }\end{array}$ & $\begin{array}{l}\text { Corruption in } \\
\text { worldwide } \\
\text { national } \\
\text { institutions } \\
\text { (politics, law, } \\
\text { media) and } \\
\text { business and } \\
\text { citizen services }\end{array}$ & $\begin{array}{l}\text { E-government } \\
\text { websites and } \\
\text { services }\end{array}$ & $\begin{array}{l}\text { Institutional theory; } \\
\text { open government and } \\
\text { transparency in } \\
\text { business transactions } \\
\text { enable and sustain } \\
\text { fair and efficient } \\
\text { markets and the flow } \\
\text { of foreign investments }\end{array}$ & $\begin{array}{l}\text { Econometric panel } \\
\text { data analysis from } \\
63 \text { countries over a } \\
4 \text {-year period }\end{array}$ & \begin{tabular}{|l|} 
Level of e-government \\
development is negatively \\
associated with corruption \\
in national institutions and \\
business and citizen ser- \\
vices; corruption in national \\
institutions is a statistical \\
mediator; most hypotheses \\
were supported
\end{tabular} & $\begin{array}{l}\text { Efforts to curb } \\
\text { corruption through e- } \\
\text { government should } \\
\text { target legal and media } \\
\text { institutions first }\end{array}$ \\
\hline
\end{tabular}

focused on authors' use of theory. As we tried to make sense of the reviews, we identified conflicting ideas of what theory is and how it should be used in IS research. From these observations, we concluded that most received definitions of theory are too restrictive, particularly but not exclusively where societal challenges are concerned. We believe that our field would do well to include in our collective definition of theory two types of theoretical contributions that we call the theory of the problem and the theory of the solution. Research articles should be encouraged to make a contribution of either type; in fact, attempting to contribute to an understanding of both of problem and its solution simultaneously might promote superficial research.

A theory of the problem aims to elucidate a specific organizational or societal challenge such as supply chain bullwhips, 
gaming addiction, inefficient business processes, or homelessness. As a contribution to the IS discipline, the problem studied will be related to ICT use (e.g., poor data quality or lack of system interoperability) or it might be a problem that ICT is expected to help solve (e.g., inefficient energy management (Ketter et al. 2016) or unproductive soil use (Jha et al. 2016). A theory of the problem would assemble (or illustrate with empirical data) different understandings of how and why a problem occurs from various relevant theories and empirical findings about conditions that make a difference in problem outcomes. The aim here is not to create a complex, comprehensive model for its own sake, but to clarify rival problem statements, explanations, and potential action levers for tackling the problem. For example, a theory of the problem of infant mortality in rural India (Venkatesh et al. 2016) might include such factors as traditional infant care practices, availability of health care facilities and professionals, education in modern health practices, and social influences from family and friends, while combining them with coherent arguments that unite the disparate parts or differentiate rival problem statements.

A theory of the problem is not a theory of the same sort as actor-network theory (Latour 2005) or communication media choice theory (Te'eni, 2001), but it is a theory — defined as an argument specifying relationships among conceptual elements - of an important substantive problem. It is rare for important substantive problems to have a single clear consensus problem statement. People often disagree on relevant outcomes, appropriate metrics, causes, and contributing factors, let alone on if or how the problem should be solved. Divergence in problem definition is often more acute when researchers study phenomenon in cultural contexts different from their own. The aim of a theory of the problem is not to gloss over these conflicts of values and beliefs but to specify the role of divergent perspectives in the problem situation.

Second, we also propose the theory of the solution as a legitimate alternative theory genre for IS research. This type of theory would address how and why ICT is expected to contribute to solving a particular organizational or societal problem, along with the additional (non-ICT) conditions necessary for the success of the ICT solution. For instance, a theory of the solution might spell out precisely how a kiosk that dispenses health information can be expected to contribute to a reduction in infant mortality in India (e.g., by countering ineffective folk practices) and the conditions that might lead to its success or failure (e.g., a trained intermediary at the kiosk, friends and family who disparage modern ideas) (Venkatesh et al. 2016). As another example, a theory of a solution to the problem of delivering government benefits safely to citizens might feature, in addition to technology, the need for intermediaries to define and evolve their own roles (Leonardi et al. 2016) or the importance of a single, well- defined and time-delimited "killer application" of benefit to citizens (McGrath 2016).

A theory of the solution is not a theory like a theory of IS implementation, but it is a theory (an argument specifying relationships among conceptual elements) of how and why ICT is expected to make a difference with respect to a specific important substantive problem in a specific context. It is not a deficiency of ICT that it cannot solve important problems all on its own: part of the value of IS scholarship is to identify the complementary assets and specific configurations associated with success.

We argue that these two theoretical contributions - of a theory of the problem and a theory of the solution-are distinct from theories of a phenomenon (such as technology use, computermediated communication, or IT governance) because theories of the problem and theories of the solution make explicit value judgments that the situation is problematic from the perspective of certain stakeholders and needs to be improved.

However, by advocating a legitimate role in IS research for substantive theories of the problem and substantive theories of the solution, we do not mean to suggest that only phenomena-focused research is valuable; nor do we aim to discourage research that is general theory-focused. Rather, we believe that the IS field can benefit from accepting these alternative theory types as legitimate conceptual innovations in several ways. First, they are likely to be more IS relevant than theories imported from other disciplines. Second, they can support IS design science efforts to create better ICT artifacts. Third, they can inform policy makers and managers. These benefits apply, we believe, not only in the context of societal challenges like those in this special issue, but also in research involving Western organizations.

\section{Evaluating Alternative Conceptuali- zations of the ICT Artifact}

Editing this special issue has reinforced our belief in the value of our field's efforts to theorize the "ICT artifact" and its role in individual, organizational, and societal outcomes. The papers in this special issue are exemplary in this regard and offer important lessons for all IS research irrespective of topic. IS researchers studying traditional Western business contexts can increase their theoretical contributions by appropriating specific theoretical insights in these papers and by emulating them in three ways: adopting appropriate definitions of the ICT artifact, focusing on technology affordances and constraints, and explicitly searching for unintended and negative consequences of ICT use. 


\section{Appropriate Definitions of the ICT Artifact}

IS researchers always face a conundrum when choosing how to define and address the ICT artifact. First, the theoretical centrality and definition of the ICT artifact concept have long been debated in our field, and different views persist (Benbasat and Zmud 2003, Orlikowski and Iacono 2001, Weber 2003). Second, there are tradeoffs between breadth and specificity of conceptualization.

Broad definitions, which include human activities (e.g., process changes and education) in addition to devices, software, and data, increase the likelihood that the researcher will capture the specific elements that make a difference in the outcomes observed. However, if definitions are too broad, critical elements and interactions may be obscured. Conversely, too narrow definitions, such as those that only include technical elements, often miss the mark. The trick is to find the right balance of breadth and specificity. For example, McGrath (2016) compared Nigeria's biometric identity verification program with those of other countries. Had she failed to examine the initial applications of the technology and the enrollment processes, she would not have been able to show how and why other programs succeeded while Nigeria's program failed.

However, the 14 papers in this special issue do not all conceptualize the ICT artifact in the same way. For example, for Ganju et al. (2016), the focus is on the number of fixed and mobile telephones and the telecommunications infrastructure for Internet access in various countries. For Chan et al. (2016), the ICT artifact is online hate-related information. Deng et al. (2016) delve into specific features of the Amazon Mechanical Turk platform along with its terms of use and the practices of requestors. Despite these differences, two main strategies emerged from the articles to achieve an appropriate balance.

First, in general, the special issue papers focused on the use of ICT artifacts, not simply their availability. Jha et al. (2016), for instance, explain how eKutir's farming applications were delivered to farmers by trained intermediaries who had financial incentives to promote application use. Díaz Andrade and Doolin (2016) describe in rich detail how refugee families make use of the personal computers and online access that were provided to them with training by the New Zealand government. Oreglia and Srinivasan (2016) show that women in China and India achieved a measure of empowerment by facilitating others' use of ICT. These papers combined a broad perspective on ICT with highly specific observations of how ICT was used.

Second, special issue authors tended to view use of ICT artifacts as a multiplex phenomenon, involving numerous types of actors with different goals and values, not just generic "users." For instance, Leonardi et al. highlight the wide range of actors involved in the process of delivering government benefits to citizens in remote areas: in addition to the government and the beneficiaries, there are banks, post offices, and retail stores. Selander and Jarvenpaa (2016) focus not only on the Swedish affiliate of Amnesty International as a user of social media, but also on the numerous individual supporters of the human rights movement, many of whom had substantially different values than the social movement organization. Careful comparisons across user types allow these authors to highlight essential theoretical elements despite very broad definitions of ICT.

We believe these strategies for addressing the conundrum posed by the ICT artifact are useful in research in traditional IS contexts, well beyond the context of grand societal challenges.

\section{Inclusion of Affordances and Constraints in Future IS Research}

Technology affordances and constraints theory (Faraj and Azad 2012; Gibson 1977, 1979; Leonardi 2011, 2013; Majchrzak and Markus 2014; Markus and Silver 2008; Treem and Leonardi 2012; Volkoff and Strong 2013; Zammuto et al. 2007) is a lens that is particularly well suited to help IS scholars build theory about ICT use. An affordance (or a constraint) is defined as an action potential; it is a relation between a technology with certain features and a users' intent or purpose to which this technology is to be used. Thus, the focus is not on how ICT artifacts can be used, but on the actors' goals and capabilities related to potential ICT artifact use. By looking at technologies as sets of affordances and constraints for particular actors, IS researchers can explain how and why the "same" technology is used or has different outcomes in different contexts, thus deepening and enriching general and substantive IS theories.

Over half of the special issue papers made some use of concepts of affordance and constraints and several more can be interpreted in that light. For example, Miranda et al. (2016) show that social media affords policy advocates some ability to dominate the discourse on an issue while allowing for a democratization of discourse in other ways. Selander and Jarvenpaa describe how social media afford a social movement organization opportunities for "glocal" engagement (simultaneous pursuit of global organizational agenda and personal agendas). The paper by Díaz Andrade and Doolin and the paper by Oreglia and Srivasan explore how ICTs afford migrants opportunities to construct new identities without losing touch with distant relations. Leong et al. (2016) and Jha et al. (2016) describe how programs to 
promote the use of online services afford individuals new business opportunities within a depressed region. Deng et al. show how Amazon's platform and policies constrain crowdworkers (e.g., from disciplining abusive requesters) while affording them low-paid work.

These specific affordances and constraints should be considered as a focus for further IS research. The affordances in these papers - of dominating a discourse, glocal engagement of customers, new identity construction, individual business development, as well as constraints on individual empowerment-are likely to be equally applicable in both nonprofit and for-profit organizations. For example, social media can afford glocal engagement to corporations; this affordance deserves deeper theorization, description, and prescription. Similarly, researchers studying businesses developing digital business strategies should examine how technology affords individual entrepreneurship, not simply organizational initiatives.

\section{Explicit Search for Unintended or Negative Outcomes}

Over the years, there have been a number of calls for IS researchers to consider the unintended or negative consequences of ICT (Ash et al. 2004; Harrison et al. 2007; Majchrzak and Markus 2013; Sawyer and Rosenbaum 2000; Sein and Harindranath 2004). However, less published IS research describes unintended or negative consequences. There are several possible explanations. Researchers might prefer to focus on antecedents of ICT use rather than on ICT's consequences. Researchers might privilege the goals of certain stakeholders rather than others (such as Amazon's business goals for Mechanical Turk rather than needs of crowdworkers). Researchers often have a pro-ICT bias and subconsciously veer away from acknowledging ICT-related harms. Reviewers might emphasize elegant theory, sophisticated method, or sensational findings, while discounting ambiguous empirical observations in publication decisions.

The papers in this special issue are exemplary in their attention to unintended, negative and even "dual" outcomes (Pool 1983). Chan et al. outcomes of ICT: the role of online information in promoting hate crimes. Ketter et al. (2016) report the unintended negative side effects (e.g., increased energy consumption) that accompanied the desired positive outcomes (lowered energy costs) during use of their simulation platform. Two papers in the special issue report dual effects, where nearly opposite effects occur simultaneously. For example, Miranda et al. strains informed public discourse on important policy questions; Deng et al. show that use of Amazon Mechanical Turk both empowers and exploits crowdworkers.
We believe this special issue demonstrates that all IS researchers should accept as default assumptions that (1) ICT can be deployed for "good" and "ill" purposes, (2) the consequences of ICT use can vary enormously, even in the same context, and (3) the effects of ICT use can sometimes be ill for some stakeholders, while also being good for others. The recognition that ICT can have both positive and negative effects, both intended and unintended, deepens our field's theorization of ICT. In addition, by remaining alert to the possibility of negative and dual effects, we can contribute to the work of design scientists who aim to develop better ICT artifacts, that is, ones that achieve better outcomes for a greater number and diversity of stakeholders.

One implication of our observations is that (use of) ICT may not always result directly in the outcomes that ICT is hypothesized to influence. ICT may be hypothesized to improve homelessness by nudging people to take their medication, but (even if people take their medications) they may not exit the state of homelessness. We believe that, while an IS scholar may hypothesize an intermediate outcome (e.g., adequate medication) as essential for a distant outcome (e.g., achievement of appropriate shelter), a reviewer should not require impact on the distant outcome as evidence that ICT has made a difference. We believe that ICT is indeed a powerful engine of societal change. However, we also believe that ICT does not operate alone. Instead "impacts" require a convergence of conditions of which ICT is only one. As a result, failure to show that ICT alone causes a particular outcome does not mean that ICT does not make a difference. A goal of our field, we believe, is to provide a more nuanced representation of how ICT impacts social phenomenon via upstream, intermediate, or downstream outcomes.

\section{Striving for a New Understanding of the Organization}

In much traditional IS research, organizations, as bounded recognizable entities with acknowledged members and managers, occupy center stage. ICTs are seen as designed and deliberately introduced by managers to achieve a clear business purpose; ICT use is seen to take place within organizational boundaries or at the interface between an organization and its customers (Wareham 2003).

The papers in this special issue, however, remind us that this view of organizations is becoming less accurate in the digital world. The focus of many of these special issue papers is not on the managers who decide what ICT to implement. Instead, the focus is on the complex systems, subsystems, networks, individuals, and actions within which ICT is embedded. Instead of terms from traditional organization theory such as 
structure, goals, task segmentation, hierarchies, and boundaries, the terms used by the papers in this special issue are those of social theory, emergence, and complexity science. A focus on goals is replaced with an emphasis on managing tensions and adaptations. A focus on understanding why people leave and join an organization is replaced with an analysis of layers of embeddedness and value alignment. A focus on structure is replaced with an exploration of the emergence of networks and the evolution of ecosystems.

Editing this special issue has convinced us that this way of reconceptualizing the organization as a complex and decentered network or system of actors has great potential utility for many traditional IS research domains. The papers in this special issue offer two promising areas of theoretical development in future IS research: the roles of intermediaries and the process of emergent digital designing.

\section{The Roles of Intermediaries}

Five special issue papers explicitly focus on the roles of individual intermediaries in helping others use ICT. Sometimes intermediaries are individuals (or small organizations) who have been deliberately selected or vetted by an organization to play the intermediary role. For instance, in Jha et al., the intermediaries are micro-entrepreneurs to whom the social entrepreneurship eKutir has given tools, training, and financial incentives to deliver agricultural services to Indian farmers rural farmers. Individual entrepreneurs play a similar rule in Leong et al.'s study of the Taobao Villages program in China. In other cases, intermediation is entirely an emergent role, as in Oreglia and Srivasan's portrait of female economic migrants in China or in Díaz Andrade and Doolin's observations of refugee families in New Zealand.

Regardless of whether the intermediary role was or was not formally designed, the papers in this special issue show that the role of intermediaries cannot be fully prescribed. Instead, intermediary roles evolved when the implicit requirements of ICT use were shown to be lacking (e.g., literacy, numeracy, and electric power). For instance, in Leonardi et al., retail store owners found they had to enter their customers' PINs and intercede for them with banks and government agencies. Furthermore, special issue papers explicitly or implicitly identify multiple formal and informal intermediaries who interact in complex ways to influence ICT use and its outcomes. For example, Venkatesh et al. examines the roles not only of the kiosk attendants hired by the Indian government to help rural women access perinatal health advice, but also the friends and family members who influence the willingness of women to make use of the kiosks and to implement the advice. Díaz Andrade and Doolin in a government-sponsored program for refugees living in New Zealand. Leonardi et al. sketch out a chain of intermediaries between government agencies and the ultimate beneficiaries.

Several papers in this special issue also show the growing role of platforms as intermediaries between use of ICT and societal outcomes. Examples include the Taobao electronic marketplace (Leong et al.), Amazon's Mechanical Turk (Deng et al.), the Power TAC simulation platform (Ketter et al.), the eKutir platform (Jha et al.), and, of course, social media (the papers by Miranda et al. and by Selander and Jarvenpaa). These papers remind us that platforms are powerful and that their governance can and should be carefully designed with an eye toward the values and needs of all actors in their networks (Wareham et al. 2014.)

This focus on platforms and on multiple overlapping intermediary roles clearly applies to much traditional IS research (Klein et al. 2011). Individuals who rent automobiles in Western countries are part of complex sociotechnical ecosystems involving not just car rental agencies, but also travel aggregators, automobile manufacturers, traffic management, location tracking, and communication and entertainment services, among others. Special issue papers afford a powerful strategy for surfacing and addressing the complex networks in which Western citizens and business organizations employ ICT.

\section{Emergent Digital Designing}

The special issue articles also call into question the historical view of organizational design that pervades much traditional IS research. Historically, organizational design was viewed as a process for creating structures to divide tasks, allocate tasks and decision-making authority to roles, motivate and reward appropriate behavior, and monitor and control through information flows (Puranam et al 2014). The historical and longitudinal investigations in special issue papers show that this view of organizational design can be too static and too simplistic, not only for societal challenges, but also for Western businesses.

The new view of organizational design that emerges in these papers replaces terms like structure, decisions, antecedents, and control by the "network" concept of social theory and complexity theory concepts of emergence, catalyst, multilevel/multilayered, iterative, and conditions. Even the simplest organization is viewed as dynamic and interdependent with multiple layers of stakeholders, rather than a static entity with well-defined boundaries. The concepts of processes and routines are forsaken; in their place are assumptions of continual evolution, localized tensions, and digital action repertoires. For example, Selander and Jarvenpaa describe how the digital action repertoires of Amnesty Inter- 
national supporters brought about a near implosion of the organization while taking localized versions of Amnesty International's message to more people than ever before. As another example, Jha et al. discuss the evolution of the eKutir ecosystem through five phases as the organization and its micro-entrepreneurs learned from experience and built on success to recruit additional partners and offer new services.

The view of emergent digital designing exemplified in certain special issue papers is highly relevant to many traditional IS research concerns. Rather than study online communities as a bounded phenomenon, IS researchers should consider examining communities as a system within multiple systems, such that each actor is a part of other communities, and that what actors do online is mutually influenced by what they do offline. In addition to studies of consumer purchase decisions that are bounded by data provided by a firm or social media site, IS researchers should also consider that a purchaser's offline context for using the purchased good may have a greater influence on the purchase decision than a few online clicks. Studies of ICT implementation could be extended to capture the continual flux among emergent layers of affected actors. Relatedly, reviewers should feel empowered to ask for justification from an author for the boundaries of the phenomenon studied and suggest modifying those boundaries if appropriate.

\section{Coupling Research Findings with Policy Suggestions}

IS researchers are often intermediaries themselves-between the research rigor of their discipline and the $\mathrm{C}$-suite executives (chief innovation, chief information, chief digital or chief executives) of the organizations they observe-whether the observations are derived from social media or e-commerce data or from interviews and ethnographies. IS researchers should take the opportunity as often as possible to offer policy recommendations to the organizations or civic structures from which the data are derived. Beyond mere recommendations, researchers can further understand how decision makers respond to them: do they shrug their shoulders, implement a small experiment, or strategize how to better serve an underserved population? Observing these reactions will enhance the design of future studies as well as increase the potential for impact, mixing rigor and relevance in an iterative cycle.

The studies in this special issue all have important policy recommendations. Because of the nature of the phenomena they study, policy recommendations are intended not only for C-suite equivalents (e.g., Amazon managers, state government managers), but also for public policy makers (e.g., legislative branches of government). For example, Chan et al.'s research on racial hate crime in the United States informs policy makers to pay greater attention to data-driven approaches for identifying lone-wolf perpetrators than to key word searches of speeches. McGrath provides guidelines for the successful deployment of identity verification systems. Leong et al. recommend encouraging local business incubation as a more successful policy approach to economic development than government assistance to rural villages. Srivastava et al. (2016) offer the policy recommendation that efforts to curb corruption through e-government should target legal and media institutions first.

The authors, then, are exemplary in designing and executing studies that provide both rigorous findings and the additional explication of their policy recommendations. It is important for IS researchers to be clear about their own policy recommendations. It may also be possible, in the final round of an accepted paper, to add a note on how the policy recommendation was received. Finally, we suggest that IS researchers should relabel their practical implications section to policy implications. There is no reason to presume that managers of businesses are the only practitioners who can benefit from our insights.

\section{Conclusion}

We hope that you will enjoy reading the 14 papers in this special issue, not only for the light they shed on today's societal challenges, but also for the lessons they offer for all IS research, regardless of context.

\section{References}

Agerfalk, P. J. 2014. "Insufficient Theoretical Contribution: A Conclusive Rationale for Rejection?," European Journal of Information System (23:6), pp. 593-599.

Ash, J. S., Berg, M., and Coiera, E. 2004. "Some Unintended Consequences of Information Technology in Health Care: The Nature of Patient Care Information System-Related Errors," Journal of the American Medical Informatics Association (11:2), pp. 104-112.

Avgerou, C. 2013. "Social Mechanisms for Causal Explanation in Social Theory Based IS Research," Journal of the Association for Information Systems (14:8), pp. 399-419.

Benbasat, I., and Zmud, R. W. 2003. "The Identity Crisis Within the IS Discipline: Defining and Communicating the Discipline's Core Properties," MIS Quarterly (27:2), pp. 183-194.

Chan, J., Ghose, A., and Seamans, R. 2016. "The Internet and Racial Hate Crime: Offline Spillovers from Online Access," MIS Quarterly (40:2), pp. 381-403. 
Deng, X., Joshi, K. D., and Galliers, R. D. 2016. "The Quality of Empowerment and Marginalization in Microtask Crowdsourcing: Giving Voice to the Less Powerful Through Value Sensitive Design," MIS Quarterly (40:2), pp. 279-302.

Díaz Andrade, A., and Doolin, B. 2016. "Information and Communication Technology and the Social Inclusion of Refugees," MIS Quarterly (40:2), pp. 405-416.

Faraj, S., and Azad, B. 2012. "The Materiality of Technology: An Affordance Perspective," in Materiality and Organizing: Social Interaction in a Technological World, P. Leonardi, B. A. Nardi, and J. Kallinikos (eds.), Oxford, UK: Oxford University Press Oxford, pp. 237-258.

Ganju, K. K., Pavlou, P. A., and Banker, R. D. 2016. "Does Information and Communication Technology Lead to the WellBeing of Nations? A Country-Level Empirical Investigation," MIS Quarterly (40:2), pp. 417-430.

Gibson, J. J. 1977. "A Theory of Affordances," in Perceiving, Acting and Knowing: Toward an Ecological Psychology, R. Shaw and J. Bransford (eds.), Hillsdale, NJ: Lawrence Erlbaum Associates, Inc., pp. 67-82.

Gibson, J. J. 1979. The Ecological Approach to Visual Perception, New York: Taylor and Francis.

Gregor, S. 2006. "The Nature of Theory in Information Systems," MIS Quarterly (30:3), pp. 611-642.

Grover, V., Lyytinen, K., Srinivasan, A., and Tan, B. C. 2008. "Contributing to Rigorous and Forward Thinking Explanatory Theory," Journal of the Association for Information Systems (9:2), pp. 40-47.

Harrison, M. I., Koppel, R., and Bar-Lev, S. 2007. "Unintended Consequences of Information Technologies in Health Care-An Interactive Sociotechnical Analysis," Journal of the American Medical Informatics Association (14:5), pp. 542-549.

Jha, S. K., Pinsonneault, A., and Dubé, L. 2016. "The Evolution of an ICT Platform-Enabled Ecosystem for Poverty Alleviation: The Case of eKutir," MIS Quarterly (40:2), pp. 431-445.

Ketter, W., Peters, M., Collins, J., and Gupta, A. 2016. “A Multiagent Competitive Gaming Platform to Addess Societal Challenges," MIS Quarterly (40:2), pp. 447-460.

Klein, R., Wareham, J., and Cousins, K. 2011. "Electronic Intermediary Functional Roles and Profitability," Decision Sciences (42:2), pp. 309-337.

Latour, B. 2005. Reassembling the Social: An Introduction to Actor-Network-Theory, Oxford, UK: Oxford University Press.

Leonardi, P. 2011. "When Flexible Routines Meet Flexible Technologies: Affordance, Constraint, and the Imbrication of Human and Material Agencies," MIS Quarterly (35:1), pp. 147-167.

Leonardi, P. 2013. "When Does Technology Use Enable Network Change in Organizations? A Comparative Study of Feature Use and Shared Affordances," MIS Quarterly (37:3), pp. 749-775.

Leonardi, P. M., Bailey, D. E., Diniz, E. H., Sholler, D., and Nardi, B. 2016. "Multiplex Appropriation in Complex Systems Implementation: The Case of Brazil's Correspondent Banking System," MIS Quarterly (40:2), pp. 461-473.

Leong, C. M. L., Pan, S-L., Newell, S., and Cui, L. 2016. "The Emergence of Self-Organizing E-Commerce Ecosystems in Remote Villages of China: A Tale of Digital Empowerment for Rural Development," MIS Quarterly (40:2), pp. 475-484

Majchrzak, A., and Markus, M. L. 2013. Methods for Policy Research: Taking Socially Responsible Action ( $2^{\text {nd }}$ ed.), Thousand Oaks, CA: SAGE Publications.
Majchrzak, A., and Markus, M. L. 2014. "Technology Affordances and Constraints Theory (of MIS)," in Encyclopedia of Management Theory, E. Kessler (ed.), Thousand Oaks, CA: SAGE Publications, pp. 832-836..

Markus, M. L. 2014. "Maybe Not the King, but an Invaluable Subordinate: A Commentary on Avison and Malaurent's Advocacy of 'Theory Light' IS Research," Journal of Information Technology (29:4), pp. 341-345.

Markus, M. L., and Silver, M. S. 2008. "A Foundation for the Study of IT Effects: A New Look at DeSanctis and Poole's Concepts of Structural Features and Spirit," Journal of the Association for Information Systems (9:10/11), pp. 609-632.

McGrath, K. 2016. "Identity Verification and Societal Challenges: Explaining the Gap Between Service Provision and Development Outcomes," MIS Quarterly (40:2), pp. 485-500

Miranda, S. M., Young, A., and Yetgin, E. 2016. "Are Social Media Emancipatory or Hegemonic? Societal Effects of Mass Media Digitization in the Case of the SOPA Discourse," MIS Quarterly (40:2), pp. 303-329.

Oreglia, E., and Srinivasan, J. 2016. "ICT, Intermediaries, and the Transformation of Gendered Power Structures," MIS Quarterly (40:2), pp. 501-510.

Orlikowski, W. J., Iacono, C. S. 2001. "Research Commentary: Desperately Seeking the 'IT' in IT Research-A Call to Theorizing the IT Artifact," Information Systems Research (12:2), pp. 121-134.

Pool, Ithiel de Sola. 1983. Forecasting the Telephone: A Retrospective Technology Assessment of the Telephone, Norwood, NJ: Ablex.

Puranam, P., Alexy, O., and Reitzig, M. 2014. "What's 'New' About New Forms of Organizing?," Academy of Management Review (39:2), pp. 162-180.

Rivard, S. 2014. "The Ions of Theory Construction," MIS Quarterly (38:2), pp. iii-xiv.

Sawyer, S., and Rosenbaum, H. 2000. "Social Informatics in the Information Sciences: Current Activities and Emerging Directions," Informing Science (3:2), pp. 89-89.

Sein, M. K., and Harindranath, G. 2004. "Conceptualizing the ICT Artifact: Toward Understanding the Role of ICT in National Development," The Information Society (20:1), pp. 15-24.

Selander, L., and Jarvenpaa, S. L. 2016. "Digital Action Repertoires and Transforming a Social Movement Organization," MIS Quarterly (40:2), pp. 331-352.

Srivastava, S. C., Teo, T. S. H., and Devaraj, S. 2016. "You Can't Bribe a Computer: Dealing with the Societal Challenge of Corruption Through ICT," MIS Quarterly (40:2), pp. 511-526.

Te'eni, D. (2001). "Review: A Cognitive-Affective Model of Organizational Communication for Designing IT, " MIS Quarterly (25:2), pp. 251-312.

Treem, J. W., and Leonardi, P. M. 2012. "Social Media Use in Organizations: Exploring the Affordances of Visibility, Editability, Persistence, and Association," Communication Yearbook (35), pp. 143-189.

Venkatesh, V., Rai, A., Sykes, T. A., and Aljafari, R. 2016. "Combating Infant Mortality in Rural India: Evidence from a Field Study of eHealth Kiosk Implementations," MIS Quarterly (40:2), pp. 353-380. 
Volkoff, O., and Strong, D. M. 2013. "Critical Realism and Affordances: Theorizing IT-Associated Organizational Change Processes, MIS Quarterly (37:3), pp. 819-834.

Wareham, J. 2003. "Information Assets in Interorganizational Governance: Exploring the Property Rights Perspective," IEEE Transactions on Engineering Management (50:3), pp. 337-351.

Wareham, J., Fox P., and Cano Giner, J. L. 2014. "Technology Ecosystem Governance," Organization Science (25:4), pp. 1195-1215.
Weber, R. 2003. "Editor's Comments: Still Desperately Seeking the IT Artifact," MIS Quarterly (27:2), pp. iii-xi.

Weber, R. 201. "Evaluating and Developing Theories in the Information Systems Discipline," Journal of the Association for Information Systems (13:1), pp. 1-30.

Zammuto, R. F., Griffith, T. L., Majchrzak, A., Dougherty, D. J., and Faraj, S. 2007. "Information Technology and the Changing Fabric of Organization," Organization Science (18:5), pp. 749-762.

\section{Appendix}

\section{The Process of the Special Issue}

Our intent in editing this special issue was to bridge what we perceived as a lack of cross-fertilization between the type of IS research that is published in MIS Quarterly and research on IS in developing countries. Despite the differences in context (e.g., Western businesses versus rural communities), we thought there should be more synergy because of the common focus on ICT. We hoped to change that with this special issue.

Therefore, we took extra effort to invite people to become associate editors and reviewers for the special issue who traditionally had not published in MIS Quarterly. We thank everyone (authors as well as editorial teams) who generously took part, making this special issue possible.

When we published our call for papers in 2013 we had no idea what to expect. Since there were already several well-regarded journals publishing research on ICT and societal challenges, we weren't sure who would be interested in submitting this research to MIS Quarterly. We were astonished at the response. Over the course of 6 months, we received so many abstracts that we, impromptu, organized a workshop at the 2013 International Conference on Information Systems in which over 50 authors presented their research to each other, giving and getting feedback and developing a community. When the closing date in March 2014 arrived, over 90 papers had been submitted to the special issue. There were so many great papers that we were able to tighten our focus to societal challenges of the sort known as "grand challenges"challenges affecting large populations of underserved people around the globe. A number of excellent papers that addressed more circumscribed societal issues (e.g., computer literacy among U.S. elderly, long commutes to work) were channeled into MIS Quarterly's regular review process.

After the first round of reviews we were somewhat taken aback by the extent to which reviewers negatively evaluated papers we believed to be promising. Our analysis of the reviewers' evaluations led us to conclude that traditional evaluation criteria of theory contribution were not appropriate to the topic of ICT and societal challenges. This in turn shaped our thoughts about alternative kinds of theoretical contributions. We also decided that MIS Quarterly's genre of Research Notes offered a useful way to feature papers that primarily make empirical contributions, and yet have important theoretical implications (Agerfalk 2014). We are particularly pleased to have accepted so many such papers for the special issue and encourage future editors to continue this practice.

Finally, we would like to offer a special thanks to Jennifer Syverson at MIS Quarterly, who patiently helped us to track papers through numerous cycles of review and revision. The first author would like to thank the National Science Foundation for its generous funding of this research (NSF No. 1219832). 
